\title{
112. On Some Properties of the Rice Dwarf Virus
}

\author{
By Teikichi FukUshi and Ikuo KImurA
}

(Comm. by S. KuSANO, M.J.A., Oct. 12, 1959)

Although the rice dwarf disease has been studied for many years there has been no information communicated about the physical and chemical properties of its causal virus probably owing to the fact that the virus in extract is not infective when inoculated to rice plants. Storey (1933), Black (1941), and Maramorosch (1949-1955) succeeded to transmit plant viruses to virus-free insect vectors by injecting juice from viruliferous insects, using fine glass needles or capillaries. The present authors attempted to transmit rice dwarf virus by inoculating virus-free leafhoppers, Nephotettix cincticeps Uhl. with extracts from infective leafhoppers or affected rice plants, anticipating that it would possibly enable them to investigate some properties of this virus. The infective insects or diseased leaves of rice plants were ground and diluted with $\mathrm{M} / 30$ phosphate buffer mixture $(\mathrm{pH}$ 6.8) and centrifuged. A small amount (approxim. 1:3,000 ml) of the supernatant fluid diluted to $1: 10-10^{6}$ was injected into the virus-free insect through a puncture made in the abdomen with a glass capillary. These leafhoppers were confined individually in glass tubes each enclosing a healthy young rice plant. The experimental results are shown in the following table.

Results of mechanical inoculation of leafhoppers with rice dwarf virus

\begin{tabular}{|c|c|c|c|c|c|c|c|c|}
\hline Virus source & Dilution & 10 & 50 & $10^{2}$ & $10^{3}$ & $10^{4}$ & $10^{5}$ & $10^{6}$ \\
\hline \multirow[t]{3}{*}{$\begin{array}{l}\text { Infective } \\
\text { leafhoppers }\end{array}$} & $\begin{array}{l}\text { No. of inoculated } \\
\text { leafhoppers }\end{array}$ & 60 & 60 & 60 & 60 & 60 & 30 & 30 \\
\hline & $\begin{array}{l}\text { Leafhoppers } \\
\text { survived more } \\
\text { than } 20 \text { days }\end{array}$ & 42 & 17 & 32 & 34 & 43 & 21 & 19 \\
\hline & $\begin{array}{l}\text { No. of infected } \\
\text { leafhoppers }\end{array}$ & $\begin{array}{c}11 \\
(26 \%)\end{array}$ & $\begin{array}{c}4 \\
(24 \%)\end{array}$ & $\begin{array}{c}3 \\
(9 \%)\end{array}$ & $\begin{array}{c}4 \\
(12 \%)\end{array}$ & $\stackrel{2}{(5 \%)}$ & 0 & 0 \\
\hline \multirow[t]{3}{*}{$\begin{array}{r}\text { Affected } \\
\text { leaves }\end{array}$} & $\begin{array}{l}\text { No. of inoculated } \\
\text { leafhoppers }\end{array}$ & 60 & 30 & 60 & 60 & 30 & - & \\
\hline & $\begin{array}{l}\text { Leafhoppers } \\
\text { survived more } \\
\text { than } 20 \text { days }\end{array}$ & 42 & 17 & 41 & 32 & 21 & - & - \\
\hline & $\begin{array}{l}\text { No. of infected } \\
\text { leafhoppers }\end{array}$ & $\begin{array}{c}6 \\
(14 \%)\end{array}$ & $\begin{array}{c}2 \\
(12 \%)\end{array}$ & $\begin{array}{c}2 \\
(5 \%)\end{array}$ & $\begin{array}{c}1 \\
(3 \%)\end{array}$ & 0 & & \\
\hline
\end{tabular}

It is evident from this table that rice dwarf virus can be mechanically transmitted to the leafhopper which will subsequently produce infections in healthy rice plants. Further, it appears that the concentration of virus in the insect bodies is somewhat greater than that in 
the diseased leaves, the virus withstanding a dilution end-point of $10^{-4}$ and $10^{-3}$ in extracted juices of infective leafhoppers and affected leaves, respectively.

As previously stated (Fukushi, 1933, 1934) the rice dwarf virus may be transmitted through eggs from an infective female leafhopper to her progeny. Accordingly an attempt was undertaken to demonstrate the virus in the egg. One hundred and ninety-nine eggs laid by 14 infective female leafhoppers were taken before hatching, ground and diluted with phosphate buffer $1: 100,1: 1,000$, and 1:10,000, respectively. A small amount of the fluid was forced into the ventral side of the abdomen of a leafhopper as described above. Four and 6 of each group of 49 leafhoppers inoculated with the extracts diluted 1 to 100 and 1 to 1,000 , respectively became infective as shown below.

Presence of rice dwarf virus in eggs of leafhopper

\begin{tabular}{ccccc}
\hline Virus source & $\begin{array}{c}\text { Dilution of } \\
\text { the extract }\end{array}$ & $\begin{array}{c}\text { No. of inoculated } \\
\text { leafhoppers }\end{array}$ & $\begin{array}{c}\text { No. of leafhoppers } \\
\text { survived more than } \\
20 \text { days }\end{array}$ & $\begin{array}{c}\text { No. of } \\
\text { infective } \\
\text { leafhoppers }\end{array}$ \\
\hline Eggs & $1: 100$ & 49 & 27 & $4(15 \%)$ \\
& $1: 1,000$ & 49 & 34 & $6(18 \%)$ \\
& $1: 10,000$ & 20 & 14 & 0 \\
\hline
\end{tabular}

The extract of infective leafhoppers was diluted to $1: 100$ and centrifuged at $10,000 \mathrm{rpm}$ for 30 minutes. The supernatant fluid was placed in a stoppered tube and stored at $0 \sim 4^{\circ} \mathrm{C}$ in a refrigerator. After 24 96 hours the infectivity of the fluid was tested by injecting it into virus-free leafhoppers. As the result of a series of experiments it was found that the infectivity of rice dwarf virus in vitro is lost when kept at $0 \sim 4{ }^{\circ} \mathrm{C}$ for 72 hours as shown in the following table.

Longevity in vitro of rice dwarf virus

\begin{tabular}{ccccc}
\hline $\begin{array}{c}\text { Duration } \\
\text { of aging }\end{array}$ & $\begin{array}{c}\text { No. of } \\
\text { inoculated } \\
\text { leafhoppers }\end{array}$ & $\begin{array}{c}\text { Leafhoppers } \\
\text { survived more } \\
\text { than 20 days }\end{array}$ & $\begin{array}{c}\text { No. of infected } \\
\text { leafhoppers }\end{array}$ & $\begin{array}{c}\text { Percentage of } \\
\text { infected } \\
\text { leafhoppers }\end{array}$ \\
\hline Control & 60 & 37 & 8 & 22 \\
$24 \mathrm{hrs}$ & 48 & 27 & 3 & 11 \\
$48 \mathrm{hrs}$ & 48 & 24 & 3 & 13 \\
$72 \mathrm{hrs}$ & 43 & 13 & 0 & \\
$96 \mathrm{hrs}$ & 30 & 24 & 0 & \\
\hline
\end{tabular}

Infective leafhoppers freeze-stored at -30 to $-35^{\circ} \mathrm{C}$ for $1,2,5$, and 8 months were ground and diluted to $1: 100$. The extract was centrifuged and a small amount of the supernatant was injected into nonviruliferous leafhoppers. 
Effect of freezing upon rice dwarf virus

\begin{tabular}{cccc}
\hline $\begin{array}{c}\text { Duration of storage } \\
\text { at }-30 \sim-35^{\circ} \mathrm{C}\end{array}$ & $\begin{array}{c}\text { No. of inoculated } \\
\text { leafhoppers }\end{array}$ & $\begin{array}{c}\text { No. of leafhoppers } \\
\text { survived more than } \\
20 \text { days }\end{array}$ & $\begin{array}{c}\text { No. of infected } \\
\text { leafhoppers }\end{array}$ \\
\hline 1 month & 30 & 16 & $6(38 \%)$ \\
2 months & 30 & 18 & $2(11 \%)$ \\
5 months & 29 & 18 & $6(33 \%)$ \\
8 months & 24 & 19 & $1(5 \%)$ \\
\hline
\end{tabular}

As shown above this virus can resist freezing at $-30 \sim-35^{\circ} \mathrm{C}$ for 5 months or longer.

The extract of infective leafhoppers diluted to $1: 100$ was centrifuged at $10,000 \mathrm{rpm}$ for 30 minutes. About $0.3 \mathrm{ml}$ of the supernatant fluid were placed in glass tube about $3 \mathrm{~cm}$ long and $0.6 \mathrm{~cm}$ in diameter, stoppered at both ends and heated in hot water at the desired temperature for 10 minutes. After cooling the infectivity of the fluid was tested by injecting into nonviruliferous leafhoppers. The results of experiments are shown in the following table.

Heat tolerance of rice dwarf virus

\begin{tabular}{cccccc}
\hline $\begin{array}{c}\text { Tempera- } \\
\text { ture }\end{array}$ & $\begin{array}{c}\text { No. of } \\
\text { inoculated } \\
\text { leafhoppers }\end{array}$ & $\begin{array}{c}\text { No. of } \\
\text { leafhoppers } \\
\text { survived more } \\
\text { than 20 days }\end{array}$ & $\begin{array}{c}\text { No. of } \\
\text { infected } \\
\text { leafhoppers }\end{array}$ & $\begin{array}{c}\text { Percentage } \\
\text { of infected } \\
\text { leafhoppers }\end{array}$ & $\begin{array}{c}\text { Latent period } \\
\text { of virus in } \\
\text { leafhopper } \\
\text { and rice plant }\end{array}$ \\
\hline Control & 60 & 40 & 12 & 30 & $29-40$ days \\
$35^{\circ} \mathrm{C}$ & 60 & 33 & 6 & 18 & $34-41$ days \\
$37^{\circ} \mathrm{C}$ & 60 & 35 & 4 & 13 & $33-48$ days \\
$40^{\circ} \mathrm{C}$ & 60 & 33 & 2 & 6 & $47-51$ days \\
$45^{\circ} \mathrm{C}$ & 30 & 21 & 0 & 0 & \\
$50^{\circ} \mathrm{C}$ & 30 & 14 & 0 & 0 & \\
\hline
\end{tabular}

As shown in this table the thermal inactivation point of this virus appears to lie between $40^{\circ}$ and $45^{\circ} \mathrm{C}$.

Infective leafhoppers were ground and diluted 1 to 50 with phosphate buffer solution and centrifuged. A small amount of the supernatant $(0.01 \mathrm{ml})$ was inoculated on to the chorioallantoic membrane of developing chick embryo on the 11th day of incubation. After 7 days' incubation the inoculated membrane was taken out and ground with addition of physiological saline or buffer solution. Success attended the effort to inoculate 210 virus-free leafhoppers with the extract of inoculated chorioallantoic membrane from 29 eggs. However, all the inoculated leafhoppers remained noninfective showing that the virus could not be cultivated in this way. 